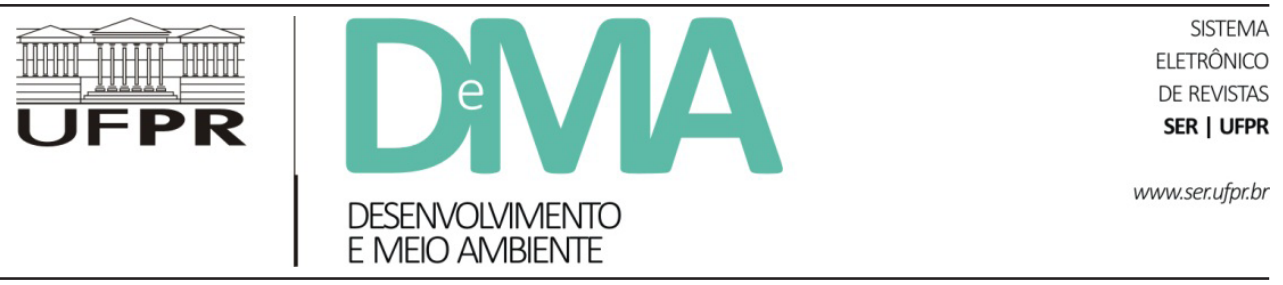

\title{
"Contradições em meio à tradição": o processo de criação da Reserva Extrativista Rio Xingu, Terra do Meio, Pará, Brasil
}

\author{
"Contradictions Amidst Tradition": The Creation Process in the \\ Xingu River Extractive Reserve, Terra do Meio [Midland] Region, \\ Pará State, Brazil
}

\author{
Roberta Rowsy Amorim de CASTRO ${ }^{1 *}$, Myriam Cyntia Cesar de OLIVEIRA² \\ ${ }^{1}$ Faculdade de Ciências Exatas e Tecnologia (FACET), Universidade Federal do Pará (UFPA), Abaetetuba, PA, Brasil. \\ ${ }^{2}$ Programa de Pós-Graduação em Agriculturas Amazônicas (PPGAA), Universidade Federal do Pará (UFPA), Belém, PA, Brasil. \\ *E-mail de contato: roberta_rowsy@hotmail.com
}

Artigo recebido em 22 de janeiro de 2016, versão final aceita em 3 de agosto de 2016.

RESUMO: $\quad$ Esta pesquisa objetivou analisar os processos de criação da RESEX Rio Xingu e a elaboração do seu Plano de Manejo, destacando como se deu a assimilação e repercussão desses processos pelas famílias ribeirinhas locais. A metodologia baseou-se na aplicação de entrevistas semiestruturadas, transcrição das mesmas, observação direta e participante e caminhadas nas áreas de uso das famílias. Foi optado pelo uso de narrativas devido ao fato de estas representarem com maior fidelidade a opinião e realidade vivenciada pelos interlocutores. No caso em estudo, a criação da Unidade de Conservação contribuiu para que fosse modificada a condição de usurpação das terras dos ribeirinhos por grileiros e fazendeiros, entretanto, foram verificadas dificuldades de assimilação pelos moradores da nova conjuntura estabelecida pela criação da RESEX e regras no seu Plano de Manejo, decorrentes, principalmente, da imposição de normatizações relacionadas a práticas tradicionalmente adotadas pelas famílias, o que influenciou no não cumprimento ou no sentimento do direito de não cumprir as regras estabelecidas, mudanças nas relações sociais e externalização de conflitos. Essa repercussão está atribuída, sobretudo, à rapidez com que foi conduzida a criação da área protegida, falhas no processo metodológico de construção do Plano de Manejo, ao comportamento passivo das famílias, quando consultadas, e à falta de maturação no diálogo entre os moradores da Reserva e as instituições envolvidas no processo de criação e gestão da mesma.

Palavras-chave: Amazônia; modos de vida; plano de manejo; populações tradicionais.

ABSTRACT: This research aims to analyze the creation processes of Rio Xingu RESEX and the preparation of its Management Plan, highlighting how the assimilation and repercussion of these processes by local riverside families was achieved. The methodology was based on the application of semi-structured interviews, transcription of the same, direct and participant observation with hiking in the areas of use of the families. The use of narratives 
was chosen because they represent more faithfully the views and reality experienced by the interlocutors. In this particular case, the creation of the conservation unit contributed to modify the riverside land usurpation condition by land grabbers and farmers, however, assimilation difficulties were observed on the locals, on the new environment established by the creation of the RESEX and about some rules in its Management Plan, due, mainly, from the imposition of norms related to traditional practices adopted by the families, which influenced in the non-compliance or the feeling of having the right to not comply with the established rules, changes in social relations and outsourcing conflicts. This impact is assigned, above all, to how fast the creation of the protection area was conducted, flaws in methodological process of building the Management Plan, to the passive behavior of the families when consulted, and to the lack of maturity in the dialogue between the reserve inhabitants and institutions involved in the creation process and its management.

Keywords: Amazon; livelihoods; management plan; traditional population.

\section{Introdução}

No Brasil, as áreas protegidas incluem diversas categorias, tais como Terras Indígenas (TI) e Unidades de Conservação (UC) que integram o Sistema Nacional de Unidades de Conservação (SNUC). Essas últimas são divididas em dois grupos, conforme sua categoria de manejo: as unidades de Proteção Integral (Estação Ecológica, Reserva Biológica, Parque Nacional, Parque Estadual, Monumento Natural e Refúgio de Vida Silvestre) e as unidades de Uso Sustentável (Área de Proteção Ambiental, Área de Proteção Ambiental Estadual, Área de Relevante Interesse Ecológico, Floresta Nacional, Floresta Estadual, Reserva de Fauna, Reserva de Desenvolvimento Sustentável, Reserva Particular do Patrimônio Natural e Reserva Extrativista).
Dentre as unidades de uso sustentável, as Reservas Extrativistas (RESEX) são áreas utilizadas por populações tradicionais, cujo sustento baseia-se no extrativismo e, simultaneamente, na agricultura de subsistência e na criação de pequenos animais. Estas foram criadas visando à proteção dos modos de vida e da cultura dessas populações, além de assegurar o uso sustentável dos recursos naturais locais (Brasil, 2000).

Historicamente, as RESEX podem ser consideradas fruto das reivindicações e articulações do Movimento Seringueiro ${ }^{1}$, sendo vinculadas à política ambiental brasileira, devido à sua proximidade com o movimento ambientalista (Allegretti, 2002; Luna, 2004; Spínola et al., 2010). Essas áreas são de domínio público, com uso concedido às populações tradicionais residentes por meio de regulamentação específica, de acordo com o disposto na lei. As

\footnotetext{
${ }^{1}$ O movimento formado pelos seringueiros no início da década de 1970, aliado a Organizações Não Governamentais (ONGs) e outras instituições parceiras, teve como um dos seus principais nomes Chico Mendes, que atuava divulgando a luta dentro e fora do Brasil. Devido a sua visibilidade e atuação em prol dos direitos dos seringueiros as suas terras e da proteção da floresta, o mesmo acabou assassinado em 22 de dezembro de 1988 (Allegretti, 2002). O crime causou grande repercussão e clamor nacional e internacional por justiça e, por meio das vozes de representantes de Governos, jornalistas, movimentos sociais, ONGs e populações tradicionais, em 1989, as RESEX foram criadas e reconhecidas como instrumentos da Política Nacional do Meio Ambiente por meio da Lei 7.804, de 18 de julho do mesmo ano. No início de 1990, foi criado o Centro Nacional de Desenvolvimento Sustentado de Populações Tradicionais (CNPT), setor do Instituto Brasileiro de Meio Ambiente e Recursos Naturais Renováveis (IBAMA) que seria responsável pela administração dessas áreas e mais um passo foi dado em relação à efetivação das RESEX. Mas, em virtude da falta de recursos orçamentários, não foi possível a sua implementação (Cunha, 2010). Contudo, em 30 de janeiro de 1990 , por intermédio do Decreto $n^{\circ} 98.897$, as RESEX foram regulamentadas, moldando uma nova concepção de Unidade de Conservação, pois preza pela defesa dos modos de vida das populações tradicionais que podem usufruir e manejar de forma sustentável os recursos naturais existentes.
} 
mesmas são geridas por um Conselho Deliberativo $^{2}$, constituído por órgãos públicos, organizações da sociedade civil e das comunidades tradicionais residentes na área. Para regulamentar as atividades realizadas pelas populações locais e as regras para visitantes, existem os Planos de Manejo; cada unidade necessita aprovar o seu Plano por meio do Conselho Deliberativo. Segundo a Lei 9.985/2000, Art. 2, Inciso XVI, o Plano de Manejo trata-se de um documento técnico, fundamentado nos objetivos gerais de uma UC, estabelecendo em seu conteúdo o zoneamento da área, a implantação de estruturas fiscais necessárias à gestão da unidade e o Plano de Utilização ${ }^{3}$, em que são definidas as normas as quais devem ser seguidas pela população residente para a concessão do direito real de uso e o manejo dos recursos naturais.

No contexto amazônico, as RESEX surgem como uma alternativa ao desenvolvimento moldado pelas políticas anteriores ${ }^{4}$, que preconizavam a adaptação da natureza para satisfação de demandas de mercados econômicos, procurando, desse modo, romper com a visão dicotômica entre sociedade e natureza, uma vez que a própria legislação brasileira que rege sobre as Unidades de Conservação passou a valorizar determinadas atividades humanas, deixando subentender que os seres humanos e a natureza podem manter relações mais integradoras, sendo geralmente as populações tradicionais residentes nestas áreas promovedoras da conservação dos recursos naturais (Castro, 2013).

Todavia, mesmo com avanços no que diz respeito à visualização da existência de modos de vida diferenciados de populações tradicionais locais, a região amazônica é tida como uma grande reserva da biodiversidade, não somente do Brasil, mas de toda a humanidade (Schweickardt, 2003; Porto-Gonçalves, 2005), portanto, considera-se que como processo de povoamento e incorporação da Amazônia ao espaço nacional, principalmente a partir da década de 1970 (Albert, 1992; Becker, 2004), as populações tradicionais passaram "a fazer parte da racionalização burocrática e administrativa própria da estrutura estatal, mas sem o devido preparo para isso" (Silva \& Simonian, 2015, p. 170). Desse modo, apesar de sua história ser arraigada em lutas e conquistas sociais, visando à permanência e perpetuação de suas populações e seus modos de vida, as RESEX atualmente se configuram como "a materialização dessa racionalidade estatal e, como tal, exigem ações pautadas em regras legalmente criadas" (Silva \& Simonian, 2015, p. 170).

\footnotetext{
${ }^{2}$ O Conselho Deliberativo é o instrumento que formaliza a administração da Unidade de Conservação, cuja presidência cabe ao ICMBio. O mesmo é constituído também por representantes das comunidades tradicionais residentes na área, organizações da sociedade civil e órgãos públicos locais e estaduais (Greco et al., 2007; Vasconcelos et al., 2010). Conforme a definição expressa na Instrução Normativa ICMBio n ${ }^{\circ}$ 02, de 18 de setembro de 2007, este "é o espaço legalmente constituído de valorização, discussão, negociação, deliberação e gestão da Unidade de Conservação e sua área de influência referente a questões sociais, econômicas, culturais e ambientais” (Brasil, 2012, p. 96).

3 “Também chamado de Plano de Uso; é o documento base para que seja firmado o Termo de Compromisso entre a população tradicional beneficiária da Unidade, que receberá a concessão do direito real de uso, e o Instituto Chico Mendes” (Brasil, 2012, p. 104).

${ }^{4}$ Após 1964, o Estado brasileiro orientou-se para a formulação de políticas que estivessem diretamente relacionadas com a promoção do desenvolvimento e acumulação do capitalismo, a modernização das instituições econômico-financeiras e a industrialização. De acordo com Matias-Pereira (1997), o processo decisório relacionado à formulação de políticas públicas envolvia diversos segmentos da elite empresarial, nacional e estrangeira, a alta tecnoburocracia estatal e, inclusive, alguns segmentos da sociedade cooptados. No que corresponde ao processo de desenvolvimento e ocupação da Amazônia, as decisões do Estado colaboraram para o surgimento de políticas públicas, cujos critérios e normas eram desconhecidos pela maior parte da população, cuja direção estava para o atendimento de interesses e conveniências de grupos influentes, que por elas se beneficiavam.
} 
Sob essa perspectiva pode-se refletir que as populações tradicionais que estiveram durante muito tempo à margem de processos legais do Estado podem, quando criadas UC de uso sustentável, ser submetidas a lógicas do campo burocrático estatal sem um preparo adequado e compreensão dessa nova realidade, o que exige das mesmas "expertise e capacidade de aplicação de conhecimentos baseados nos estatutos" (Silva \& Simonian, 2015, p. 169). Assim, compreende-se que apesar de as RESEX corroborarem a manutenção das populações e culturas tradicionais (Brasil, 2000), contradições podem existir, principalmente no que se refere às normatizações que são estabelecidas no processo de criação das mesmas e no Plano de Manejo, que, em alguns casos, pode ir de encontro aos costumes, tradições, práticas e relações sociais que, historicamente, já faziam parte do cotidiano das populações residentes. Sobre a temática, Pinton \& Aubertin (1997) destacam que as RESEX são um experimento social passível de riscos de desvios, uma vez que podem promover mudanças nas relações de nível fundiário, bem como nas relações com os recursos naturais e modificações das relações econômicas e sociais, estabelecendo novas territorialidades e regras.

Considerando tais reflexões, este artigo tem como objetivo analisar os processos de criação da RESEX Rio Xingu e a elaboração do seu Plano de Manejo, destacando como se deu a assimilação e a repercussão desses processos pelas famílias ribeirinhas locais.

\section{Metodologia}

\subsection{Lócus de pesquisa}

A pesquisa foi realizada em quatro comunidades da RESEX Rio Xingu, sendo elas: Baliza, Pedra Preta, Morro Grande e Morro do Félix. A RESEX Rio Xingu está localizada no município de Altamira, Estado do Pará, fazendo parte do Mosaico de Unidades de Conservação da Terra do Meio $^{5}$ (Figura 1), que representa uma barreira de contenção ao chamado arco do desmatamento da Amazônia, servindo também para conter a expansão da fronteira agrícola na região. A RESEX possui uma área de, aproximadamente, 303.841 hectares, limitando-se ao norte e a oeste com a Estação Ecológica (ESEC) Terra do Meio, ao sul e também a oeste com o Parque Nacional (PARNA) Serra do Pardo e a leste com as Terras Indígenas (TI) Apyterewa e Araweté do Igarapé Ipixuna (Brasil, 2012).

\subsection{Método, técnicas e amostra}

O método baseou-se no princípio da saturação teórica, em que foi incluída na pesquisa a quantidade de interlocutores necessários até que ocorresse a saturação e nenhuma categoria nova ou relevante aparecesse (Bartalotti et al., 2008).

Os dados foram coletados durante duas visitas no território da RESEX, ocorridas nos meses de ju-

\footnotetext{
${ }^{5}$ A região que compreende a Terra do Meio é muito rica em biodiversidade e se constitui em um dos maiores mosaicos de áreas de conservação do mundo. Nessa região encontram-se diversas áreas protegidas federais e estaduais, como Terras Indígenas (TI), um Parque Nacional (PARNA), uma Estação Ecológica (ESEC), uma Floresta Nacional (FLONA), uma Floresta Estadual (FLOTA), uma Área de Proteção Ambiental Estadual (APA) e três Reservas Extrativistas (RESEX) (Vasconcelos \& Siqueira, 2008). A Terra do Meio é assim chamada por estar localizada no "meio" do estado do Pará na área de interflúvio dos rios Xingu e Tapajós. A região representa $6 \%$ das terras do estado e abrange 38,62\% do território do município de Altamira, 19,25\% de São Félix do Xingu e uma pequena porção de Trairão, municípios que se desenvolveram ao longo das rodovias BR 163 - Cuiabá-Santarém - e da BR 230 - Transamazônica (Velásquez et al., 2006).
} 


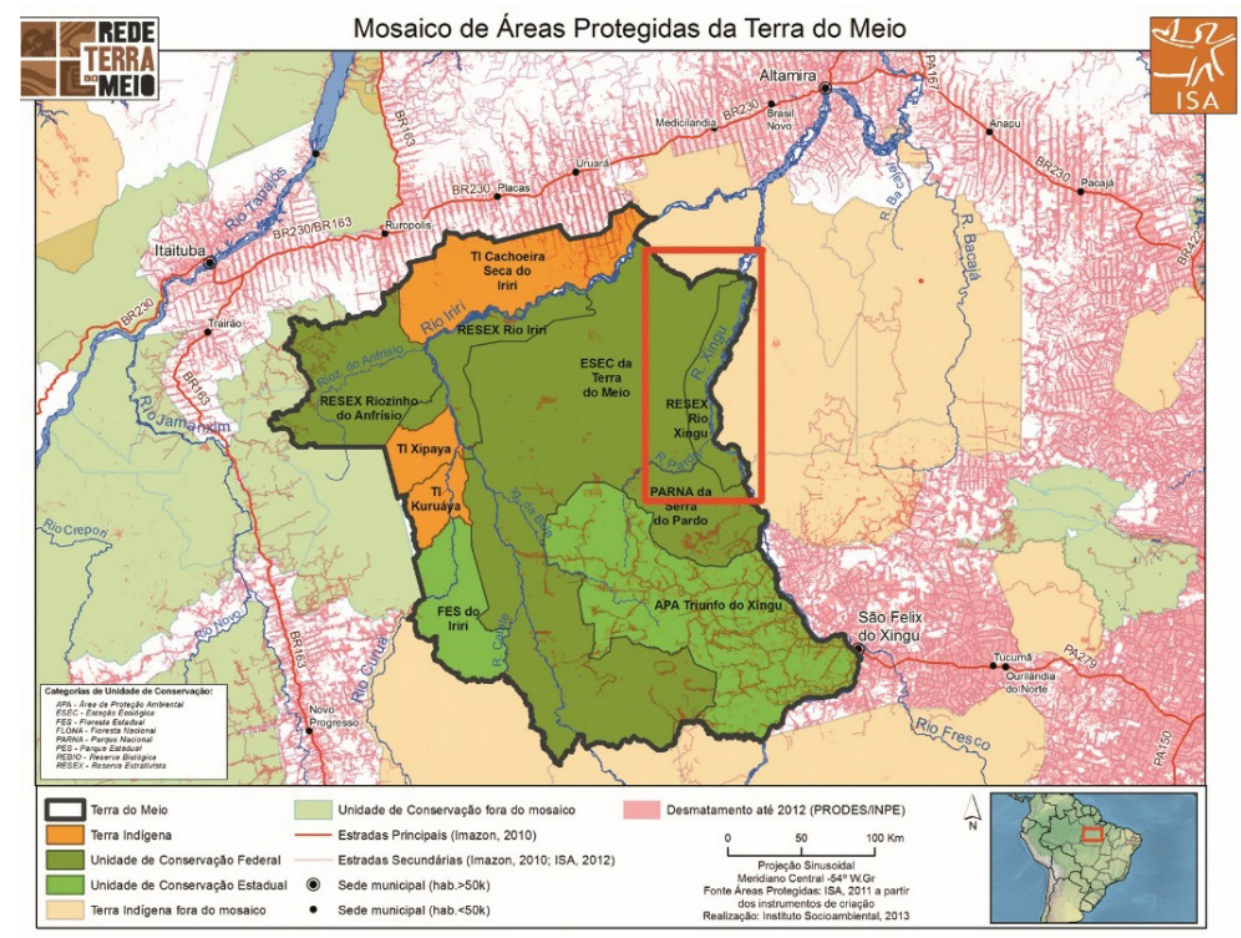

FIGURA 1 - Mapa de localização das Unidades de Conservação da Terra do Meio, com ênfase na RESEX Rio Xingu.

FONTE: Laboratório Geoprocessamento/Instituto Socioambiental - ISA (2014).

nho e julho de 2012, onde utilizou-se como técnica as entrevistas semiestruturadas, com uso de roteiro pré-elaborado. Durante as visitas, verificou-se que a referida RESEX possuía 44 famílias residindo em sua área, das quais foi retirada a amostra de 23 famílias $^{6}$, que foram visitadas, entrevistadas e acompanhadas em suas atividades cotidianas, por meio de observações diretas (Chizzotti, 2003) e participantes $^{7}$ (Martins, 1996; Malinowski, 1998), além de caminhadas nas áreas de uso das mesmas.

No roteiro utilizado para entrevistas, foi solicitado aos interlocutores que falassem, de acordo com suas percepções, sobre a atual conjuntura da UC, o histórico de sua criação, bem como sobre o processo de construção do Plano de Manejo e do Plano de Utilização da área. Além disso, foram

\footnotetext{
${ }^{6}$ A pesquisa não teve como critério uma amostragem probalística. Todas as famílias entrevistadas já residiam na RESEX Rio Xingu antes de sua criação e participaram direta ou indiretamente da construção do Plano de Manejo da mesma. Adotou-se, nesse trabalho, que participação direta refere-se à presença física e ativa nas reuniões que subsidiaram a elaboração do Plano de Manejo e a participação indireta está relacionada às famílias que participaram ou não dessas reuniões e que adotaram, em alguns casos, uma postura mais pacífica, não atuando efetivamente nas decisões, conforme as definições de participação de Diaz Bordenave (2007).

${ }^{7}$ Os usos dessas metodologias partiram do pressuposto de que observar e participar são ações necessárias para entender melhor o cenário e seu contexto, sendo melhor do que simplesmente perguntar. Usando dessas estratégias metodológicas, as respostas vêm com o tempo, juntamente com a observação e a participação (Malinowski, 1998).
} 
solicitadas informações relacionadas à procedência e à atividade familiar (se nascido ou morador antigo; procedência de pais e cônjuges, atividades realizadas antes da criação da RESEX - histórico e conjuntura atual). Também foi perguntado se já tinham ouvido falar em RESEX, se sabiam qual o seu significado e finalidades desse tipo de UC, se conheciam as normas e quais as suas opiniões sobre as mesmas, e se algo havia mudado após a implantação da Reserva. Durante a pesquisa, tanto homens quanto mulheres foram estimulados a responder, pois as entrevistas foram realizadas com os membros familiares que estavam presentes, de forma a estimular o debate sobre as respostas solicitadas.

No território da RESEX, o deslocamento até as casas das famílias foi feito nas embarcações dos próprios ribeirinhos ${ }^{8}$, para os quais, em alguns casos, foi fornecido combustível para realização das viagens em pequenos trechos. Além disso, "caronas" com ribeirinhos e regatões ${ }^{9}$ foram muito úteis, pois, além do acúmulo e registro de informações, ofereceram a possibilidade de contato com praticamente todas as famílias residentes na Unidade e a prática de conversas informais a fim de obter mais informações relevantes que não haviam sido mencionadas durante a aplicação das outras metodologias.

As informações foram registradas em caderno de campo e as entrevistas foram gravadas e, posteriormente, transcritas com fidedignidade, sendo as narrativas fonte de dados relevante para o entendimento do cenário da RESEX após a sua criação, por meio do relato oral de seus moradores.
A opção pelo uso da narrativa enquanto fonte principal de dados deu-se pelo fato de que "a narrativa, como habilidade humana, revela a relação entre o indivíduo e a cultura, contribuindo para o desenvolvimento ou a manutenção de atitudes e valores em contextos específicos e, por conseguinte, de significados" (Costa \& Gualda, 2010). Ainda segundo as autoras, as narrativas não são somente relatos de experiência: elas representam e favorecem a experiência compartilhada e a organização do comportamento, sendo o tempo e o espaço referências essenciais para a compreensão das experiências, além de representar a pluralidade das relações entre os sujeitos e os acontecimentos.

Por fim, procurou-se também analisar documentos como a Lei no 9.985/2000 e os Planos de Manejo e Uso da RESEX Rio Xingu, a fim de compreender as normas estabelecidas e relacionar as mesmas com as opiniões emitidas pelos moradores em suas narrativas.

\section{Do que trata o Plano de Manejo e quais as suas especificações? Uma breve análise}

O Sistema Nacional de Unidades de Conservação (SNUC), que rege sobre as Unidades de Conservação brasileiras, no Artigo 23, dispõe sobre as condições para posse e uso das áreas ocupadas pelas populações tradicionais em áreas de Reservas Extrativistas e Reservas de Desenvolvimento Sustentável. O parágrafo $1^{\circ}$ dispõe que "as populações de que trata este artigo obrigam-se a participar da

\footnotetext{
${ }^{8}$ Ribeirinhos e moradores, neste trabalho, são termos utilizados como sinônimos, correspondendo às pessoas ou famílias que residem na área da RESEX Rio Xingu.

${ }^{9} \mathrm{O}$ regatão é um comerciante ambulante que viaja entre as cidades e comunidades do rio, comercializando mercadorias em troca de produtos regionais agrícolas e extrativistas. Na Amazônia, o regatão tem uma história controversa, visto por um lado como um herói pioneiro, trazendo a civilização para populações isoladas, e, por outro lado, como um atravessador, explorando os pobres produtores e roubando comerciantes locais em seus negócios (McGrath, 1999).
} 
preservação, recuperação, defesa e manutenção da unidade de conservação" (Brasil, 2000). O parágrafo $2^{\circ}$ desse mesmo artigo estabelece normas para uso dos recursos naturais por estas populações, instituindo nos incisos:

I - a proibição do uso de espécies localmente ameaçadas de extinção ou de práticas que danifiquem seus habitats;

II - a proibição de atividades e práticas que impeçam a regeneração natural dos ecossistemas;

III - demais normas estabelecidas na legislação e no Plano de Manejo da unidade e no contrato de direito real de uso (Brasil, 2000).

A partir das regulamentações expostas nessa Lei, percebe-se que existe a possibilidade de múltiplas interpretações sobre as possíveis penalizações que as populações tradicionais podem sofrer pela prática de determinadas atividades. Ao apenas definir proibições, a lei não especifica quais as atividades que podem ser realizadas nas RESEX, tampouco as exemplifica, o que permite que, em muitos casos, por desconhecimento dessas regras, as populações realizem atividades que já faziam parte do seu cotidiano e que foram, a partir da criação da Unidade, consideradas proibidas.

Sobre essa temática, Arruda (1999) reflete que, a despeito das suas boas intenções, o modelo de Unidades de Conservação adotado no Brasil pode apresentar consequências indesejáveis. Mesmo quando são implantadas UC de uso sustentável, que prezam pela manutenção das comunidades tradicionais locais, estas comunidades evidentemente não estão livres de sofrer impactos sobre seu modo de vida. Conforme destaca Brito (1995, apud Vianna, 2008), em geral, a criação de UC produz mudanças de variados graus de intensidade no que diz respeito à dinâmica seguida pelas populações residentes em relação à apropriação e ao uso dos recursos naturais. Arruda (1999) analisa ainda que a partir da implementação de uma área protegida, alguns atos corriqueiros podem passar a ser criminalizados, como, por exemplo, a caça, a pesca, a utilização dos recursos da floresta, a retirada da lenha para cozinhar, etc., uma vez que muitas espécies animais ou vegetais que historicamente eram utilizadas e consumidas pela população tradicional local no seu cotidiano podem ter seu uso proibido, desconsiderando os aspectos culturais e sociais estabelecidos ao longo de gerações. Isso significa dizer que, para uma população que possui determinado costume, existem dificuldades para modificá-lo sem que haja apoio institucional externo para a valorização de suas tradições e cultura e entendimento do "novo" cenário que está sendo construído com a criação da Unidade.

O Plano de Manejo possui como um de seus componentes o Plano de Utilização ou Plano de Uso, que delimita as ações quanto ao uso dos recursos naturais por parte dos moradores locais, isto é, as regras que devem ser seguidas pelas populações locais para garantia de sua permanência na área. Não diferente, na RESEX Rio Xingu, as relações internas, o contrato de concessão de direito real de uso, bem como o uso dos recursos naturais foram normatizados e formalizados nesses documentos, sendo que o processo de elaboração será pauta de análise adiante.

\section{O processo de construção do Plano de Manejo da RESEX Rio Xingu e suas limitações: reflexões a partir das narrativas dos interlocutores}

A região da Terra do Meio, onde hoje está localizada a RESEX Rio Xingu, é povoada por populações tradicionais nativas e/ou migrantes que 
se estabeleceram na área em períodos históricos, como o primeiro e o segundo Ciclos da Borracha, compreendidos entre 1870 e 1910 e 1940 e 1945 , respectivamente. Nesses períodos, as populações locais se submetiam a seringalistas patrões, por meio do sistema de patronagem e aviamento ${ }^{10}$. Com a saída dos patrões, os moradores da região passaram a sofrer outro tipo de coação exercida por fazendeiros, grileiros, posseiros, madeireiros e especuladores, o que em muitos casos, influenciou famílias inteiras a abandonarem suas residências e seus modos de vida, passando a viver em situação de miséria nas periferias das cidades de Altamira e São Félix do Xingu.

Esse cenário de constantes pressões, ameaças e violência, foi intensificado a partir dos anos 2000, influenciando para que os moradores da região se mobilizassem, buscando apoio de organizações governamentais e não governamentais em prol da proteção de suas terras e modos de vida. Após muitas discussões, lutas e reivindicações para garantir os direitos das populações tradicionais locais e frear o processo de grilagem, constatou-se que seria necessária a implantação de UC que formariam um mosaico de proteção para a região e suas populações. Assim, depois de diversos estudos, entre os anos de 2004 e 2006 foram criadas várias áreas protegidas na região. Para completar o objetivo proposto para o mosaico, foi solicitada a criação da RESEX Rio Xingu, sendo esta oficializada, por meio de decreto, em 05 de junho de 2008 (Castro, 2013). Cabe ressaltar que, nesse processo, nem todas as famílias se mobilizaram ou tiveram acesso a informações sobre o que estava ocorrendo, interna e externamente, em prol da criação de áreas protegidas para a região.

Posteriormente à criação da RESEX Rio Xingu, foram realizadas visitas às famílias pelos órgãos responsáveis a fim de marcar reuniões para formulação do Plano de Manejo ${ }^{11}$ da UC. Ocorreram no total cinco reuniões, sendo que quatro delas foram realizadas cada uma em comunidade específica e com a participação dos moradores desta, além de uma reunião ampliada, que contou com a presença de moradores de todas as comunidades da RESEX. Essas reuniões tinham uma proposta que visava à participação das famílias da área, uma vez que, segundo o SNUC (Brasil, 2000), o uso de metodologias participativas é quesito obrigatório no processo de construção de Planos de Manejo das Unidades de Conservação de Uso Sustentável no Brasil, por possibilitar maior proximidade das decisões e normas com a realidade e os modos de vida locais.

Entretanto, para os interlocutores, a metodologia utilizada, embora primasse pela participação das famílias locais, não ofereceu clareza da situação, das informações e dos processos, visto que pouco foi explicado (durante as reuniões) sobre o que estava acontecendo e quais seriam os objetivos da criação da RESEX (tendo em vista que a mesma já havia sido decretada). Para a situação relatada, compreende-se que há casos em que a participação é até estimulada, contudo isso não é garantia de que

\footnotetext{
${ }^{10}$ Modelo de servidão por dívida, que se perpetuou na Amazônia durante o ciclo da borracha, e passou a regular as relações sociais dos trabalhadores dos seringais. "Ele se firmou como um modelo de relacionamento entre o trabalhador e o patrão derivado da dominação do tipo patrimonial. No aviamento, o núcleo da relação de trabalho parece se constituir em variações de um duplo sistema de crédito sem dinheiro, bancário e comercial, em que os juros são cobrados extorsivamente ao longo da cadeia de financiamentos que vai da casa exportadora de borracha ao trabalhador do seringal" (Martins, 1997, p. 98).

${ }^{11}$ No caso da RESEX Rio Xingu, ao mesmo tempo em que foi construído o Plano de Manejo da Reserva, também foi formado o Conselho Deliberativo da RESEX Rio Xingu, oficializado por meio da Portaria no 59 de 27 de julho de 2010 (Brasil, 2012, p. 95-96).
} 
ela seja sempre igualitária. Milani (2006) destaca que em processos em que se busca a participação dos atores locais, estes são consultados e solicitados durante o processo de tomada de decisões, contudo, eles participam, na melhor das hipóteses, somente antes e depois da negociação. Desse modo, a participação existente contribui para aumentar a transparência de dispositivos institucionais, mas não garante, porém, a legitimidade do processo institucional na construção do interesse coletivo.

Considerando esse argumento, as normatizações e regras na RESEX Rio Xingu foram discutidas sem que os ribeirinhos que residem na área tivessem a noção real sobre o que tratava a ação naquele momento, culminando na falta de entendimento dos mesmos sobre as normatizações que estavam decidindo, conforme destacado no trecho:

Construíram esse Plano mais que na doida. Eles faziam assim: como era que os seus pais faziam isso e isso assim? Nós gastava tanto tempo. E agora? Agora nós só gasta a metade. E eles (expressão de anotação)... Quantas linhas de terras vocês querem pra plantar? Ah, eu só gasto uma linha. É só uma linha??? E quem era mais esperto gritava: uma linha é pouco, bota dez linhas aí. Ai fomos, até que chegamos na discussão de oito linhas de roça na discussão. E disse: olha, quanto vai ser de terra pra vocês? O governo vai dar pra vocês quinze quilômetros de terra pra trás. Assim não, assim nós que divide. Ai começaram. Como é a caça? Vocês caçam até aonde? Ai o fulano disse: eu só caço ali ao redor de casa. Ai anotavam "só ali ao redor de casa". Ai nisso nós fomos se prejudicando. Aí a pesca? O que vocês usam pra pescar? Ah, a gente usa a malhadeira, a tarrafa. A tarrafa não pode que é proibida por lei (eles disseram). Ai o fulano grita: ah, mais malhadeira também não quero. Ai perdemos as duas. (E11, mulher, 34 anos)

A partir dessa narrativa é possível perceber que as famílias não tinham entendimento sobre a nova realidade na qual estavam sendo imersas, regrando atividades que antes eram cotidianas, isto é, as mesmas desconheciam o que significava ser uma RESEX, o Plano de Manejo e suas implicações. Essa afirmativa se justifica pelas respostas dadas pelos interlocutores, uma vez que, quando perguntados a respeito do seu conhecimento e entendimento sobre o que se tratava uma Reserva Extrativista e sobre as atividades que poderiam ser feitas, estes responderam de maneira vaga e imprecisa, destacando somente que "a natureza devia ser preservada". Isso nos dá evidências de que, no momento da construção do Plano de Manejo, as famílias não possuíam uma compreensão clara sobre o conceito e as bases que motivam a criação desse tipo de Unidade de Conservação, pois, além da preservação ao meio ambiente, são áreas que buscam também manter os modos de vida das populações que as habitam.

Destaca-se ainda nessa perspectiva que as populações tradicionais historicamente tiveram seus modos de vida ligados "a valores e processos não formais de conduta" e, diante da criação de uma UC, passam a ser orientadas a agir sob a lógica racional do Estado, com um comportamento balizado em marcos legais, o que exige das mesmas "conhecimento, habilidade argumentativa e edificação de uma cultura organizativa" (Silva \& Simonian, 2015, p. 164); todavia, essas características necessitam de tempo para serem construídas, o que não ocorreu na RESEX Rio Xingu devido à mesma ter sido criada "às pressas". Segundo os interlocutores, muitas famílias ficaram sabendo da criação da RESEX somente após sua decretação, pegando-as de surpresa. Isso se deve ao fato de que somente poucas lideranças locais, próximas de instituições e movimentos sociais de Altamira e região, estavam a par das ações que visavam à implantação da UC, acompanhando e auxiliando o processo. Assim, ao serem entrevistadas, as famílias 
destacam que este processo foi rápido. No entanto, lideranças locais, movimentos sociais, organizações governamentais e não governamentais já estavam atuando em prol da criação de áreas protegidas na Terra do Meio desde o ano de 1999. No caso da RESEX Rio Xingu, esta foi demandada devido a fortes pressões de grileiros, posseiros, fazendeiros e madeireiras sobre os moradores locais e suas terras, as quais, em muitos casos, foram usurpadas sob a apresentação de documentos falsos, o que exigiu agilidade na implementação da Unidade devido ao fato de muitas famílias estarem sendo coagidas a sair de suas terras (Velásquez et al., 2006; Silva, 2010; Castro, 2013).

Assim, para os interlocutores, uma das razões a que se atribui a falta de compreensão dos mesmos em relação ao que é uma RESEX está relacionada à velocidade com que foi conduzido o processo de sua criação e construção do Plano de Manejo. Embora, na concepção dos moradores, houvesse, por parte das instituições engajadas na criação da RESEX, esforço na tentativa de explicação sobre a situação da área naquele momento (nas reuniões, após a mesma ter sido oficializada via decreto) e as normatizações que seriam impostas, a rapidez na realização das reuniões para elaboração do Plano de Manejo e, principalmente, a linguagem utilizada parecem ter prejudicado o bom entendimento das famílias locais, não permitindo a efetividade da comunicação: a população local não conseguiu entender a linguagem técnica dos "de fora" (como eles chamam os não moradores), segundo destacado nas narrativas:

Tu sabe[s] qual foi [a] decisão que eu achei errada? Porque olha, muita gente aqui, na maioria, não sabe o significado das palavras. Quando for passar as informação[ões] das coisas lá de fora tem que passar na linguagem ribeirinha, beiradeiro ${ }^{12}$.(E11, mulher, 34 anos)

Agora... sabe por que esse pessoal aqui... quando vem esses pessoal de fora... sabido, eles não conversam o português claro. Tá entendendo? Às vezes tem muito beiradeiro aqui... tu tá conversando... eu tou conversando... talvez tu não pode tá entendendo o que eu tô falando. Então... eu não tô falando o português. [...] Ai eles tão falando aqui... o ribeirinho não tá entendendo. Ai eles pegam... chegam aqui com um papel... é né... coisas que eles pega... "Assina aqui". Nem o próprio ribeirinho não tá sabendo o que ele vai assinar... às vezes é alguma coisa boa... outras ruim. Ai depois que assina... leva pro computador e pronto. Já era... assinou... tá aqui. (E15, homem, 29 anos)

A dificuldade de assimilação das explicações que os "de fora" tentavam dar ocorreu em virtude das diferenças de significados de várias palavras ou termos, conforme exemplo relatado por um ribeirinho: ao decidirem que um lago ficaria para procriação, os ribeirinhos entenderam que o lago seria para criação (por desconhecimento do vocábulo procriação). Assim entenderam que o lago seria para que os peixes se reproduzissem em abundância para que, posteriormente, a população pudesse pescar no local. No entanto, o termo procriação para os "de fora" visava à preservação, à reprodução e à procriação das espécies, não podendo o lago ser utilizado como local de pesca. Esse tipo de situação de falhas de linguagem e significações não é incomum. Pimbert \& Pretty (2000, p. 196) destacam que mesmo em casos em que existe a participação popular podem ocorrer declarações públicas que nada têm a ver com as definidas pelo

\footnotetext{
${ }^{12}$ Autodenominação utilizada pelos moradores da RESEX Rio Xingu. Resumidamente, para eles o termo "beiradeiro" significa quem nasce, vive ou mora na "beira" do rio/da água (na margem do rio).
} 
público que participou, visto que "os termos utilizados significam coisas diferentes para pessoas diferentes". Sobre essa temática, Freire (1983) esclarece que não existe a possibilidade de relação comunicativa se entre os sujeitos não se estabelece a compreensão em torno da significação dos signos e, provavelmente, foi essa compreensão que não se tornou efetiva para a população da RESEX, o que ocasionou erros de interpretação das regras estabelecidas. Diaz Bordenave (2007, p. 68) acrescenta destacando que "sem comunicação não pode existir a participação. De fato, a intervenção das pessoas na tomada de decisões requer pelo menos dois processos comunicativos: o de informação e o de diálogo", o que, de acordo com os discursos das famílias, parece não ter ocorrido.

Outro fator que determinou a escolha das regras estabelecidas no Plano de Uso foi a postura passiva das famílias nos momentos das reuniões. Segundo os interlocutores, por timidez diante da "inteligência" dos "de fora", várias pessoas deixaram de opinar e se mantiveram caladas, concordando com o que estava sendo estabelecido. Estas destacaram que adotaram essa postura por receio de sofrer repressões caso discordassem do que estava sendo estabelecido nas reuniões sob o comando de autoridades externas.

Ao manter essa postura e achar que caso fossem contra o que estava sendo proposto poderiam sofrer algum tipo de penalização, os ribeirinhos acabaram corroborando leis relacionadas ao uso dos recursos naturais, atividades de subsistência e regras de convivência das quais, em muitos casos, demonstraram discordância durante as entrevistas, conforme relato:

Eu considero é aquela coisa... quando um pequeno... às vezes que ele é tão inocente... ou tão se chamado de não sabido. Quando ele ver a presença das autoridades... eu acho que pra falar... ele se aparenta... ele fica parentado... Fica nervoso. Fica nervoso... e não pode falar/não vai falar o que se aproveita.... vai falar uma coisa que acha que os grandes tava... desapoiando ele daquela atitude assim [...] Eu acho assim que é falta de conhecimento. E os pessoais não falaram: "gente se vocês não quiser... não é obrigado". Eles colocavam em pauta... e os pessoais achavam que era obrigado a fazer aquilo... sabe. Porque tem pessoas que nunca sentou na frente da autoridade pra conversar. Tá entendendo. Aí quando ver uma autoridade... fica nervoso. Tá entendendo. Aí o cara não vai dizer: "eu já fazia isso... antes eu já fazia antes" [...] Toda a tradição... ou seja... a cultura... eles próprios mudaram por não saber dizer não, nós quer como era antes. Viram a presença dos grandes... e achou que se pedisse como era antes... achou que os grandes iam querer proibir. (E15, homem, 29 anos)

Ostrom (1987, apud Feeny et al., 2001) nos fornece elementos que auxiliam na análise desse cenário. Estes destacam que as características sociais e políticas de populações que manejam recursos de uso comum, bem como a maneira como estas se relacionam com um sistema político dominante, afetam a habilidade das mesmas em organizar e manejar essa propriedade. No caso da RESEX Rio Xingu, as famílias se viram diante de uma situação desconhecida, e, estrategicamente, visando à proteção dos seus modos de vida, mantiveram-se, em certos momentos, passivas diante das decisões que estavam sendo estabelecidas pelos seus pares.

As situações relatadas evidenciam o desconforto dos moradores em participarem mais efetivamente da construção do Plano de Manejo e suas normatizações. Esse desconforto, conforme as narrativas, foi motivado pela falta de entendimento do novo cenário de criação da RESEX, pelo constrangimento diante da linguagem dos "de fora" e pelo receio de sofrer algum tipo de penalização, caso houvesse discordância com o que estava sendo estabelecido como regra. Mesmo com essas limitações, o Plano de Manejo e o Plano de Uso foram construídos. 


\subsection{Após a construção do Plano de Manejo: e agora, que normas são essas? \\ Opiniões e ações dos moradores sobre as "novas" regras}

No Plano de Manejo aprovado para a RESEX Rio Xingu foram instituídas regras para situações ligadas ao cotidiano das famílias residentes na Unidade. Estabeleceram normas relacionadas a: 1) Localidades e moradores; 2) Atividades extrativistas; 3) Atividades agrícolas; 4) Pesca; 5) Animais silvestres; 6) Entrada de não moradores; e 7) Penalidades ${ }^{13}$ (Brasil, 2012).

No que diz respeito às regras relacionadas a localidades e moradores e à entrada de não moradores, a principal norma regulamentava que caso filhos e parentes de ribeirinhos residentes desejassem morar na RESEX deveriam redigir uma carta a ser lida na presença da maior parte dos moradores, para posterior encaminhamento ao Conselho Deliberativo que, após análise, daria o parecer (Brasil, 2012). Os ribeirinhos acreditam que algumas especificações dessa norma são desnecessárias, pois vão de encontro aos costumes que tinham antes da criação da RESEX. Essas famílias acham esta regra inconveniente, afinal sempre receberam parentes a passeio sem que houvesse a necessidade da autorização, como demonstrado no trecho:

Pra mim... outras que eu também sou contra. Eu tenho parentes do lado de fora lá... quando vem visitar a família... tem que passar por um processo. Isso eu também sou contra... Se fosse uma porta fechada que entrasse só por uma porta... ai tudo bem né?.... tem que passar lá... mas aqui... entra e sai... sobe e desce. Esse plano eu sou contra. (E19, homem, 43 anos)

Sobre essa regra, após a pesquisa ter sido realizada, foi publicado oficialmente, em meados de 2013, o Plano de Manejo da Unidade e esta norma havia sido modificada, estabelecendo as especificações mencionadas somente para pessoas desconhecidas dos moradores da RESEX e não mais para filhos e parentes dos mesmos, o que reflete que algumas das solicitações de mudanças das normas sugeridas nos discursos das famílias foram atendidas, considerando o histórico de seus modos de vida antes da criação da RESEX.

Em relação às atividades extrativistas, também há discordâncias. Por exemplo, existe uma regulamentação que impõe que, caso seja encontrada alguma árvore de mogno ou castanheira caída, é necessário que o ribeirinho entre em contato com o Instituto Chico Mendes de Conservação da Biodiversidade (ICMBio) para que um representante do órgão possa se deslocar da cidade de Altamira à RESEX, até o local onde encontra-se a árvore caída, para marcação das coordenadas de sua localização por meio de GPS, tirar fotos e realizar análises e anotações sobre o motivo e o tempo da queda da árvore, para, em seguida, analisar se o ribeirinho pode usar a madeira da mesma. Somente após o recebimento da autorização é que as famílias poderão retirar e usar a madeira. Sobre a regra, as famílias entrevistadas se mostraram contrárias e essa insatisfação decorre dos inconvenientes de ordem prática que ela gera, conforme depoimentos:

\footnotetext{
${ }^{13}$ Este item diz respeito às sanções que poderão sofrer os ribeirinhos que descumprirem as regras estabelecidas. Em primeiro lugar, aquele que descumprir as regras será chamado à atenção e registrado em carta o acontecido, bem como a ciência (notificação) ao morador. Em caso de reincidência, o Conselho Deliberativo irá decidir se há possibilidade de outra chance ou não e novamente registra em carta a notificação. Caso o descumprimento da regra se repita, o ribeirinho será expulso da RESEX, sendo eliminado do cadastro de moradores e perdendo todos os direitos.
} 
Tem que ser assim. Mas tá errado... porque nós mora aqui dentro. Nós somos dono daqui. Esses caras de fora não mora aqui... quem mora é nós. Só vem aqui... é passear... né. [...] A senhora pode dizer... "não, não corta aquele pau... não". Negativo. Nós toma conta daquele pau... porque nós tamos precisando. Nós tamos naquilo que é nosso [...] Se tem uma castanheira bem ali... eu não vou pegar o meu motor serra... pra derrubar aquela castanheira seca... não. Eu tenho que pegar um pessoal do ICMBio e ir lá... bater a foto... pra levar lá em Altamira... pra saber que essa castanheira tá seca... tá morta. Eu acho que isso é uma regra que não podia ter. Não podia. Podia ter pros de fora... se fosse pra vender.. mas pra nós cercar uma casa... pra nós fazer uma porta... uma canoa... não podia ter essa regra. Não é verdade?... Nós que somos morador nascido. Eu plantei tudo e tá aqui... né. Então... eu acho que essa regra não podia ter... não é verdade? Eu acho que isso... não pode funcionar [...]. E aí... como é que faz uma regra dessa? Eu acho que uma regra dessa não podia existir dentro de uma reserva desta. Eu derrubo. Eu derrubo logo. Tenho uma canoa ali. Derrubei ali. Acolá fiz outra. Aqui acolá eu derrubo uns pés. Eu não vou meter o passo como essa canoa aí... em cinco dias... em seis dias eu vou é trabalhar pra fazer uma canoa... Pra baixo eu passo seis dias. Eu faço uma hoje... amanhã o cara pede outra canoa... eu não vou ter condição de ir em Altamira. Eu nunca. Se os caras me prender... eles podem me prender. (E14, homem, 31 anos)

Sabe como é que é? É que nem castanheira. A lei diz que a gente não pode usar castanheira. Mas se ela estiver morta a gente poderia usar porque ela já morreu, né não? A lei ficou dita assim: se por acaso um ribeirinho acha uma castanheira, mesmo estando morta, e querer serrar a madeira pra fazer a madeira pra ele, ele tem que descer em Altamira, vai atrás de um fiscal que vem aqui ai vai tirar uma foto, medir o tamanho, vai raciocinar quanto tempo tem que aquela castanheira caiu. Se ela realmente tá morta. Ai volta pra lá vai correr atrás dos proclamas tudinho pra poder liberar pra ele serrar, vai ver se foi o vento que arrancou, ou se foi de velha que ela caiu. Agora tu me diz: nós que moramos toda a vida aqui, a gente vai ter dinheiro pra sair daqui e ir atrás de tudo isso? O cara tava precisando pra fazer uma porta ontem e vai esperar três meses depois. No começo quando elas (as regras) foram imposta[s] que foi colocada nós cumprimos elas tudinho. Mas a partir do ano passado quando as regras dali foram ditada[s] que a gente entrou em desacordo porque a gente pediu pra elas ser revista [...] Toda a vida a gente tirou a madeira. A gente tirou pra fazer a canoa, a gente tira pra fazer uma casa e nós nunca desmatamos nada. Acho isso horrivel. (E11/2, homem, 57 anos)

Para atender essa norma, o ribeirinho necessita se deslocar até a cidade de Altamira e esse percurso é difícil, podendo piorar mais ainda dependendo da época do ano; é preciso ainda arcar com as despesas provenientes da estadia e alimentação na cidade enquanto sua reivindicação é analisada pelo ICMBio; além disso, o tempo gasto na viagem compromete as atividades de subsistência e, consequentemente, pode afetar a renda mensal das famílias, pois, geralmente, as viagens são realizadas nos barcos dos regatões, que fazem o trajeto em no mínimo três dias, os quais são contabilizados como perdidos. Assim, pode-se ponderar que a construção das regras sem o entendimento efetivo das mesmas pelos ribeirinhos os distancia de tal maneira da norma que eles não a sentem como algo válido, negociado, acordado. Estas acabam sendo vistas como uma imposição externa às suas vontades, o que tem como consequência direta o não cumprimento, ou o sentimento de direito de não cumprir aquilo com o que não estão de acordo e que está em oposição ao que praticavam.

Ainda em relação às atividades extrativistas, outro questionamento das famílias relaciona-se à necessidade de pedido de autorização para exploração de alguns castanhais. Esta regra é direcionada às famílias que não residem na RESEX e têm castanhais ativos na área e para famílias moradoras da RESEX que possuem castanhais em outras UC próximas, como a Estação Ecológica da Terra do 
Meio. Durante a pesquisa, duas famílias que se enquadram nesses casos foram entrevistadas. Em ambos os casos, as mesmas questionam a obrigação da autorização para explorarem os castanhais que foram estabelecidos por seus ancestrais. No caso da família que possui castanhais na área da ESEC Terra do Meio, a mesma é contrária à demarcação desta Unidade, por acreditar que seus castanhais deveriam fazer parte do território da RESEX e não da ESEC. No entanto, mesmo discordando do procedimento que precisam fazer para explorar os castanhais, estas destacaram que sempre cumprem a regra, solicitando a autorização anualmente. A afirmação foi comprovada a partir da visualização de várias autorizações escritas emitidas pelos gestores da UC, que ficam sediados no ICMBio de Altamira.

Considerando essa realidade Porro et al. (2012) discorrem que o reconhecimento dos grupos tradicionais requer a garantia de seus direitos, que são legitimados a partir da proteção às práticas sociais, as quais incluem as diversas maneiras de criar, fazer e viver. Corroborando tal afirmativa, Silva \& Simonian (2015, p. 169) refletem que as "populações tradicionais, que se adaptaram às realidades ambientais amazônicas há centenas de anos, sempre estiveram ligadas a um modo de vida baseado em valores comunitários não formais, repassados de geração a geração e cristalizados através dos tempos". Desse modo, uma mudança brusca em certos costumes e tradições vai de encontro a todo um modo de vida ou uma maneira de viver historicamente construído, o que permite refletir que as regras estabelecidas na RESEX Rio
Xingu parecem não satisfazer aos requisitos mencionados pelos autores supracitados. As narrativas demonstram que as normas foram assimiladas e repercutidas de forma negativa pelas famílias da área, uma vez que as mesmas se veem diante de situações em que as atividades antes praticadas de forma habitual hoje necessitam de autorização e que as tornam passíveis de penalizações, caso haja o descumprimento.

Essa afirmação se legitima a partir do momento em que as famílias discordam das regras. Tal conjuntura pode ser explicada tomando como referência o ponto de vista de Bourdieu (2004), que reflete sobre os modos de existência alheios a princípios de regulamentação. No caso da RESEX Rio Xingu, a regularidade das práticas, ou seja, na repetição de determinados costumes, existe o habitus ${ }^{14}$, cuja existência permanece alheia a qualquer situação regrada e regulada e é justamente o habitus que permite que as condutas dos indivíduos se mantenham à margem de qualquer referência às regras. Essa mesma análise cabe a outras situações e regras estabelecidas para os moradores da RESEX.

No que tange à atividade pesqueira, o Plano de Utilização delimita os utensílios que podem ser empregados na realização da pesca, define os locais onde as famílias podem pescar e discorre sobre as penalidades em caso de descumprimento das regras. Desse modo, no Plano consta que a tarrafa é proibida, porém, os ribeirinhos não têm esse entendimento e destacam que a mesma está liberada em pequena quantidade e tamanho. É provável que o entendimento sobre a permissão do uso do apetre-

\footnotetext{
${ }^{14}$ Bourdieu (1983, p. 60-61 apud Witkoski, 2010) compreende "As estruturas construtivas de um tipo particular de meio (as condições materiais de existência características de uma condição de classe), que podem ser apreendidas empiricamente sob a forma de regularidades associadas a um meio socialmente estruturado, produzem habitus, sistemas de disposições duráveis, estruturas estruturadas predispostas a funcionar como estruturas estruturantes, isto é, como princípios geradores e estruturados das práticas e representações que podem ser objetivamente 'reguladas' e 'regulares' sem ser o produto da obediência a regras, objetivamente adaptadas a seu fim sem supor a intenção consciente dos fins e o domínio expresso das operações necessárias para atingi-los e coletivamente orquestradas, sem ser o produto da ação organizadora de um regente”.
} 
cho foi induzido pelo próprio Plano de Manejo ao mencionar que "pode ser utilizada uma tarrafinha pequena para pegar isca", porém, a especificação/ tamanho de que trata o termo "pequena" não é exemplificada. Assim, as famílias, destacam que o uso da tarrafa deveria ser permitido, por fazer parte da tradição, em que os pais e/ou avós que trabalhavam nos seringais faziam uso constante da mesma para garantir a janta após um longo dia de caminhadas nas estradas de seringa, como afirmado no depoimento:

Proibir a tarrafa eu sou contra... a tarrafa vem desde dos tempos do meu pai... pra pegar o peixe... pra comer, gente... não é pra vender não... pra comer. Pra pegar um curimatá... oh! Meu Pai... eu ainda me lembro... Meu Pai... quando eu terminava de defumar a borracha. O meu tio pegava a tarrafa pra pegar pra comer a semana... pra não empalhar aquele dia [...] eu não queria... como eu falei... não é pra vender. É pra gente comer. O que adianta gente... empatar a gente ter a tarrafinha da gente desde o começo do mundo... que os nossas pais pegava aquele horror de curimatá. O meu pai botava no sol... e dava pra semana toda. Pra comer pra não empalhar um dia de seringa. Agora não pode ter nem pra comer... ter uma tarrafa. [...] a tarrafa... gente... eu não queria que tirasse... que a tarrafa não é pra vender.. pra venda. Eles (do ICMBio) pensam que as pessoas vai pegar o peixe pra vender. Não é pra vender... eles foram bem claro na reunião que teve ai. Eu acho que eles pensam assim. [...] Se eu tivesse uma tarrafa... eu não ia pegar peixe pra vender. Eu ia pegar pra comida. (E5, mulher, 54 anos)

Percebe-se que o discurso em prol da manutenção da cultura e dos modos de vida está no âmago das tradições perpetuadas por gerações pelas famílias. Portanto, existe uma interdependência entre "os saberes dos antigos" e o cotidiano das populações tradicionais, os quais conduzem a compreensão dos conhecimentos tradicionais como "produtos históricos", constituídos pela continuidade (Cunha, 1999, p. 156). Logo, existe uma consciência coletiva (Durkheim, 2004), sob a qual se mantêm e constituem os valores sobre os quais se efetivam as condutas coletivas e individuais dos moradores, uma vez que estes carregam a tradição e formas pretéritas de relações sociais. Assim, ao proibir o uso da tarrafa, a metodologia utilizada na construção do Plano de Manejo não considerou essas peculiaridades inerentes aos seus modos de vida, conforme narrativa:

Algumas regras aí eles vão consertando devagar né... vão se entendendo... vão tomando conhecimento. $\dot{E}$ eu falo pra minha família aqui... eu não acostumo mais muita regra... Mas os meus filhos eles já vão crescer dentro dessas regras... eles já vão, vão ensinar outros lá na frente já. Eu que já tou com quarenta anos. A tradição velha já é um pouquinho mais diferente de algumas que apareceu. Ai foi indo e ficou a tarrafinha de pegar isca. "Não, a de pegar isca pode". Não sei mais o que lá. Meu amigo por que não deixa as duas? É isso ai que tá... o meu pai nunca largou uma tarrafa... pra poder criar nós. É isso que a regra... que os pessoal... que foi colocado que eu acho errado. Eles falavam assim... o que os pais de vocês... os avôs de vocês faziam antigamente... vocês podem continuar fazendo. Ai depois de cumprir essas regra... como é que nós não pode? Aí.. por eles vem de lá... e aí põe essa regra aqui dentro. Aié essa situação de eu falar que nós fica prejudicado... porque nós não vamo ter um rio... uma localidade... pro outros vim lá de fora e tá mandando meio mundo de coisa que nós não tinha antigamente. Aí... nós se complica... nós cumprir por conta aquelas regras por conta do outros. Não é isso?... Nós que mora aqui... que fumo nascido e se criado aqui dentro. Então... eles não pode fazer esse tipo de coisa. E a malhadeira também, eu não tenho tarrafa de pegar peixe grande... eu não tenho malhadeira. Ai eu tava falando outro dia... eu vou comprar uma pra mim. Eu vou comprar uma tarrafa de pegar curimatá. Ai no dia que eles vim... eu digo... olhe eu comprei uma tarrafa pra mim e uma malhadeira pra mim pegar a 
boia pra mim comer. Eu nunca fui pescador de meio mundo de mil... quatrocentos... duzentos... trezentos metros de malhadeira não... vão me pegar aí e dizer... os pessoal do IBAMA fecharem esse tipo de coisa... pessoal do coisa lá... como é? (E20, homem, 43 anos)

O trecho demonstra a dificuldade de assimilação das normas pelas populações tradicionais da RESEX, haja vista que essa apropriação necessita de uma "cultura de ação formal exigida pelo campo burocrático-administrativo estatal, constituindo-se em um hábito a ser construído" (Silva \& Simonian, 2015, p. 169) e essa construção ainda está em processo, como destaca o interlocutor: "É eu falo pra minha família aqui... eu não acostumo mais muita regra... Mas os meus filhos eles já vão crescer dentro dessas regras... eles já vão, vão ensinar outros lá na frente já" (E20, homem, 43 anos). Ao afirmar que não se acostuma com a regra, o mesmo demonstra o valor afetivo às tradições, à consciência coletiva (Durkheim, 2004) e ao habitus (Bourdieu, 2004). Entretanto, afirma que os filhos podem se habituar, isto é, o mesmo demonstra consciência do processo adaptativo que estão passando, embora não deixe de demonstrar sua insatisfação atual.

Relatos de insatisfação semelhantes também são mencionados em relação à malhadeira. No trecho, o morador destaca seu descontentamento com a proibição do uso do apetrecho e destaca possuir uma:

Pois espinhel... não pode... tarrafa não pode... malhadeira não pode. Agora eu digo pra senhora... digo pra quem quiser ver... a malhadeira que eu tenho... eu não saio sem ela... porque o dia que eu não poder mariscar com ela?... eu boto bem aí. Eu já falei pra ele... quem quiser pode pegar.. que ai eu vou tomar providência se pode isso (E12, homem, 54 anos).

Embora somente 26\% dos interlocutores afirmem possuir malhadeiras pequenas e grandes (com malhas menores que $12 \mathrm{~cm}$ entre os nós), nos quintais de diversos moradores que asseguraram não possuir malhadeira o utensílio estava presente e podia ser visualizado. Ademais, em aproximadamente $56 \%$ das narrativas as famílias fizeram denúncias relativas ao uso de malhadeiras por vizinhos próximos, o que permite refletir que o número de famílias que utilizam o apetrecho pode ser maior do que o citado durante as entrevistas.

No item animais silvestres, destaca-se que estes só podem ser caçados para alimentação e esta deve ser realizada nos limites da RESEX, sendo proibida a comercialização. Além disso, quando estes animais são encontrados ainda pequenos devem ser criados soltos, situação à qual as famílias não expuseram nenhuma opinião contrária, visto que as normas estabelecidas no Plano de Uso estão de acordo com aquelas que já faziam parte das práticas tradicionais das mesmas. Sobre essa norma, os interlocutores não fizeram comentários significativos e, a partir das observações, foi possível constatar que a caça é realizada somente para o consumo e, quando criam animais silvestres, estes vivem sempre soltos nos quintais e proximidades das residências.

Em relação às Atividades agrícolas, o Plano de Manejo estabelece que o tamanho máximo das áreas destinadas para o cultivo deve ser de 16 linhas de roça por ano (equivalente a aproximadamente 5,28 hectares/ano). Neste caso, os interlocutores informaram que suas áreas são pequenas em virtude da pouca força de trabalho disponível devido à distribuição do tempo para atividades diversas. Os mesmos destacaram que, ao longo dos anos, as aberturas realizadas para produção agrícola nunca foram grandes, mesmo as feitas por seus ancestrais, pois o espaço destinado para os cultivos sempre garantiu a subsistência das famílias, aliado a outros meios de obtenção de alimentos e reprodução social, como 
caça, pesca, coleta, etc. O tamanho reduzido das áreas de plantio foi verificado por meio de caminhadas e visitas às roças, que no caso das famílias da RESEX Rio Xingu se resume, principalmente, ao cultivo de mandioca para produção de farinha e em escala bem menor a cacauicultura.

Para analisar a conjuntura relacionada às normas sobre animais silvestres e atividades agrícolas, pode-se tomar como referência as reflexões de Diegues (2001a), que afirma que as representações que as comunidades tradicionais fazem dos diversos habitats que utilizam se constroem a partir de uma relação de maior ou menor controle sobre o meio físico. Assim, ao continuar mantendo os seus sistemas tradicionais conforme a cultura herdada, as famílias concretizam a relação que têm com os recursos naturais. Pimbert \& Pretty (2000, p. 196) destacam em seus trabalhos que "a população não tem compromisso de manter ou apoiar novas práticas" quando não existem incentivos por parte de instituições externas ligadas ao poder público.

Concordando com o aporte teórico dos autores supracitados, analisamos que existe uma gama de situações pelas quais os ribeirinhos passam e estão passando. Essas se relacionam não só com as tentativas de adequação e adaptação às normatizações, mas também às maneiras como eles percebem estas regras e, em alguns casos, as burlam, consciente ou inconscientemente. No que diz respeito ao cumprimento das regras, cabe ressaltar ainda que, embora os interlocutores tenham destacado que descumprem as normas, não houve relatos de penalizações sofridas. Contudo, os mesmos destacam que os gestores os aconselham para que atuem em conformidade com o que foi estabelecido.

Ao refletir sobre se as famílias cumprem ou não o que foi estabelecido, se adaptando ou não ao novo cenário imposto pela criação da RESEX e à construção do seu Plano de Manejo, relativizações devem ser feitas, pois mesmo as famílias citando diversos motivos para justificar o descumprimento a algumas normas, o que deve ser lembrado é que essas famílias sempre tiveram um modo próprio de realizar suas atividades, possuindo relações sociais, saberes, tradições e costumes construídos e reconstruídos por gerações a partir das relações com os recursos naturais. Essa herança cultural, aliada à empiria cotidiana, construiu o próprio savoir-faire - saber-fazer (Allut, 2001; Arruda \& Diegues, 2000), que interfere no modo como estas famílias se apropriam dos recursos naturais de que dispõem e das normas, isto é, apesar de saberem da existência de novas regras, em muitos casos o que prevalece é esse saber-fazer, pois é nele que se alicerçam ao realizarem suas atividades cotidianas.

A partir das narrativas dos moradores sobre as normas estabelecidas, pode-se considerar que nem sempre o Estado ou uma figura político-institucional externa, materializada na figura da RESEX e suas normatizações, consegue a priori implementar, efetivamente, uma organização interna diferente da existente anteriormente, atendendo aos novos parâmetros burocráticos estabelecidos na figura de leis. Isto não quer dizer que não possa ocorrer situação semelhante à mencionada por Diegues (2001b), que analisa que existem circunstâncias em que grupos comunitários, ao sentirem seus modos de vida ameaçados, conseguem reagir, inventando e reinventando seus sistemas de reprodução material, social e simbólica. Logo, devemos entender a criação da RESEX como um processo em construção, em que paulatinamente podem ocorrer adaptações, tanto nos modos de vida quanto nas normas que a regem, conforme a norma de visita de familiares, que foi modificada atendendo a tradição das famílias.

Nesse processo em construção, destaca-se que, no que tange às relações sociais, foi mencionada nos depoimentos a existência de discórdias e de- 
savenças decorrentes dos diferentes entendimentos que as famílias têm sobre as regras, o que não quer dizer que anteriormente à criação da RESEX estas relações não existiam. Todavia, os conflitos, que porventura já ocorriam, ao serem impulsionados pelas distintas concepções das famílias sobre as normas estabelecidas no Plano de Uso, tornaram-se perceptíveis ao serem externalizados, conforme narrativa:

Agora o que é parte ruim da RESEX... foi algumas leis que foi criada. Essas mudanças aí... que gerou muita fofoca. Você tá fazendo uma coisa ali... o cara já olha ali... já inventa e já leva pro seu fulano. Aí você tá fazendo uma coisa ali... aí o cara vê e já cresce mais, leva pro seu Beltrano. Essas partes é ruim. Mas pra mim a RESEX foi boa. Só da gente ter a proteção de Deus... e ter a proteção das autoridades competentes... a gente já ganhou muito com isso aí... a gente já ganhou muito com isso aí. Agora essas regras que imporam aqui dentro é que algumas delas não devia ter. Porque tirou o nosso costume de como era antes... privou a gente. Mas não é... as pessoas que confundem as coisas. A maioria dos ribeirinhos... eu acho que não tem conhecimento do que que é RESEX. E ai faz uma fantoche de uma crença que não existe. A $i$ qualquer coisa... "ah! Vamos dizer que é tal fulano... tal fulano... fez não sei o que... ah! Foi tal ciclano”. Ai acabou a paz e a harmonia entre as pessoas. De primeiro tinha... né. Tinha antes. Hoje... por causa das leis... eu já vi coisa aqui que às vezes você bota um pano de rede ali... que eu já ouvir falar.. que colhe... um pai de família ter um pano de rede. Aí o cara vai ali... ver que é proibido... diz: "Fulano... vai lá no rádio... fulano tava com dez panos de redes". (E15, homem, 29 anos)

Há uma relação dialética nesse processo. Pela narrativa, afirma-se a emergência de conflitos coletivos decorrentes das regras impostas, o que gera nas famílias o sentimento de desesperança, ao acreditarem que estão imersas em um ambiente de sujeição, regado de normas, que segundo elas foram fortemente influenciadas por decisões externas. Ademais, as famílias da RESEX Rio Xingu destacam que muitas regras foram estabelecidas, porém, as condições para que estas fossem cumpridas não estavam objetivadas ou não foram subsidiadas, o que abre margem para a reflexão dos ribeirinhos de que a RESEX foi criada somente para proteção ambiental, visto que não existe prioridade para melhoria das condições de vida local, ou seja, os mesmos acreditam que, involuntariamente, estão sendo estimulados a abandonar a área, devido ao descaso que sofrem por parte das instituições governamentais e políticas públicas. Considerando tal realidade, Medeiros \& Young (2011) destacam que ainda há um grande número de UC com diversificadas lacunas e fragilidades, decorrentes, dentre outros aspectos, da carência de recursos. É importante considerar ainda que a gestão dessas áreas se limita também por questões administrativas, conforme assinalam Carregosa et al. (2015).

No caso da RESEX Rio Xingu, ainda que existam alguns projetos subsidiados por ONGs e instituições públicas, visando melhorar o manejo dos recursos e agregar renda aos ribeirinhos, estes não conseguem alcançar todas as famílias e ter um efeito notório, pois, como já exposto, a comunicação, o entendimento sobre as regras e a externalização dos conflitos entre as famílias dificultam a união entre os moradores para que os mesmos acordem vantagens ou subsídios para o bem coletivo e talvez seja por isso que não conseguem estabelecer um sistema organizacional eficiente do ponto de vista das relações sociais, financeiras e políticas.

Mesmo as RESEX sendo um modelo de Unidade de Conservação que objetiva garantir os direitos das populações locais e a manutenção dos seus modos de vida, casos como o da RESEX Rio Xingu revelam que ainda existem falhas no modelo, como afirmam Diegues (2001a; 2001b) e Almeida 
(2008). Assim, considerando que "nenhum padrão global é aplicável a todos os comuns do mundo" (Goldman, 2001, p. 50), o modelo atual de RESEX, considerando a pesquisa realizada, carece de ser melhorado do ponto de vista que haja suporte para que os moradores entendam e concebam o novo cenário em que foram imersos e possam se articular social e financeiramente para manterem seus modos de vida, pois a lógica dos direitos de indivíduos que compartilham recursos naturais de uso comum é mais apropriada do que a de governos distantes, que possuem uma visão restrita de determinadas realidades (Goldman, 2001), o que não implica que instituições governamentais e não governamentais não devam cumprir seus papéis enquanto mediadores de conflitos, executores de projetos e gestores do processo em construção.

\section{Considerações finais}

A pesquisa evidenciou que, assim como abordam algumas literaturas, o modelo de Reservas Extrativistas, proposto como um avanço para garantia dos direitos das populações tradicionais concomitante à preservação socioambiental, ainda necessita ser repensado, considerando que a interferência do Estado, na figura de instituições e gestores, pode, a priori, impor regras que não fazem parte do cotidiano das comunidades tradicionais, como ocorreu na RESEX Rio Xingu.

No caso em estudo, a criação da Unidade de Conservação contribuiu para que fosse modificada a condição de usurpação das terras dos ribeirinhos por grileiros e fazendeiros. Entretanto, há de se considerar que o novo cenário formado a partir da criação de RESEX, conjuntamente à elaboração do seu Plano de Manejo, ao mesmo tempo em que garante direitos, deve ser pensado como uma situação em que são propostas e impostas situações de gestão e uso da área que nem sempre condizem com o modo de vida das populações e que as normatizações não são incorporadas simultaneamente e com a mesma intensidade por todas as famílias, pois demandam tempo de adaptação, e que em alguns casos podem gerar resistência em virtude das regras estabelecidas.

Em relação às regras que apresentam concordância com o modo como as famílias geriam os recursos, não há grandes problemas, como os tamanhos dos roçados e a atividade da caça. Porém, o mesmo não pode ser dito em relação às atividades da pesca e ao uso de madeira, em que as regras, ou por apresentar restrições ao uso ou burocracias que as famílias tiveram que lidar, são objeto de discussões e descumprimentos.

Deve-se relativizar ainda que o problema não está no não cumprimento das normas pelas famílias, mas na imposição dessas, não devendo as famílias ser criminalizadas por suas atividades tradicionais. Não são as regras ou o Sistema Nacional de Unidades de Conservação que criaram a Unidade de Uso Sustentável, mas o modo de vida das populações residentes que permitiu e impôs a criação dessa categoria. Portanto, a preservação desses modos de vida é o objetivo principal dessas Unidades, o que não quer dizer que, em alguns casos, populações tradicionais não possam produzir efeitos nocivos ao meio ambiente em função de suas ações. Não há, portanto, o bom ou o mal nessa relação, o que existe são diferentes percepções de diferentes atores sobre uma mesma realidade. Recomenda-se, no contexto de conflitos entre UC e comunidades tradicionais, que haja um processo de negociação que garanta, no mínimo, condições para que as famílias mantenham sua dignidade e garantam sua reprodução social.

É evidente que, para que os modos de vida dessas populações possam ser garantidos, estas 
devem deixar de ser "invisíveis" do ponto de vista das políticas públicas. Embora avanços nesse sentido tenham ocorrido, as populações tradicionais ainda vivem em condições difíceis, como no caso da RESEX estudada, onde há poucos programas ou políticas de incentivo produtivo e econômico, por parte de poder público. Algumas ações pontuais ocorrem, principalmente, alavancadas por institui-

\section{Referências}

Albert, B. Terras indígenas, política ambiental e geopolítica militar no desenvolvimento da Amazônia: a propósito do caso Yanomami. In: Léna, P.; Oliveira, A. E. (Orgs.). Amazônia: a fronteira agrícola 20 anos depois. 2. ed. Belém: CEJUP; Museu Paraense Emílio Goeldi, 1992. p. 37-58. (Coleção Eduardo Galvão)

Allegretti, M. H. A construção social de políticas ambientais: Chico Mendes e o Movimento dos Seringueiros. Brasília, Tese (Doutorado em Desenvolvimento Sustentável - Gestão e Política Ambiental) - Universidade de Brasília, UnB, 2002.

Allut, A. G. O conhecimento dos especialistas e seu papel no desenho de novas políticas pesqueiras. In: Diegues, A. C. (Org.). Etnoconservação: novos rumos para a proteção da natureza nos trópicos. 2. ed. São Paulo: NUPAUB-USP; Hucitec; Annablume, 2001. p. 101-123.

Almeida, A. W. B. Terra de quilombo, terras indigenas, "babaçuais livres", "castanhais do povo", faxinais e fundos de pasto: terras tradicionalmente ocupadas. Manaus: PGSCA-UFAM, 2008.

Arruda, R. "Populações tradicionais" e a proteção dos recursos naturais em Unidades de Conservação. Ambiente \& Sociedade, 2(5), 79-92, 1999. Disponível em: <http:// www.scielo.br/pdf/asoc/n5/n5a07.pdf $>$.

Arruda, R.; Diegues, A. C. Os saberes tradicionais e biodiversidade no Brasil. São Paulo: NUPAUB-USP; Brasília: Ministério do Meio Ambiente, 2000.

Bartalotti, C. C.; Yonezaki, C.; Nascimento, V. do; Correa, M. B.; Almeida, R. Z. de; Manoel, M. C.; Carvalho, M. G. de; Alvarez, A. P. F. O. Concepções de profissionais de ções não governamentais. Considerando que estas populações pouco têm para garantir a sua reprodução social, a não ser a partir dos seus próprios conhecimentos e recursos naturais disponíveis, há de se pensar em políticas que unam e valorizem esses conhecimentos, de forma com que as famílias possam, também, garantir a sua sustentabilidade econômica. educação e saúde sobre Educação Inclusiva: reflexões para uma prática transformadora. O mundo da saúde, 2(32), 124130, 2008. Disponível em: <http://www.saocamilo-sp.br/ pdf/mundo_saude/59/124a130.pdf>.

Becker, B. K. Amazônia: geopolítica na virada do III milênio. Rio de Janeiro: Garamond, 2004.

Bourdieu, P. Coisas ditas. Tradução de Cássia R. da Silveira e Denise Moreno Pegorim; Revisão técnica de Paula Monteiro. São Paulo: Brasiliense, 2004.

Brasil. Lei Federal no 9.985, de 18 de julho de 2000. Institui o Sistema Nacional de Unidades de Conservação. Brasília: DOU de 19/7/2000.

Brasil. Plano de Manejo da Reserva Extrativista Rio Xingu. Ministério do Meio Ambiente. Instituto Chico Mendes de Conservação da Biodiversidade, 164 p. 2012. Aprovado pela Portaria ${ }^{\circ} 62$, de 18 de maio de 2012. Brasília: DOU de 21/5/2012. Disponível em:<http://www.icmbio.gov. br/portal/images/stories/imgs-unidades-coservacao/PM-RESEX-Rio-Xingu-2012.pdf>.

Carregosa, E. A.; Silva, S. L. da C.; Kunhavalik, J. P. Unidade de Conservação e comunidade local: uma relação em construção. Desenvolvimento e Meio Ambiente, 35, 305319, 2015. doi: 10.5380/dma.v35i0.40563

Castro, R. R. A. Comunidades tradicionais e unidades de conservação no Pará: a influência da criação da Reserva Extrativista Rio Xingu - Terra do Meio, nos modos de vida das famílias locais. Belém, Dissertação (Mestrado em Agriculturas Familiares e Desenvolvimento Sustentável) Universidade Federal do Pará, UFPA, 2013. 
Chizzotti, A. Pesquisa em ciências humanas e sociais. São Paulo: Cortez, 2003.

Costa, G. M. C.; Gualda, D. M. R. Antropologia, etnografia e narrativa: caminhos que se cruzam na compreensão do processo saúde-doença. História, Ciências, Saúde - Manguinhos, 17(4),925-937, 2010. Disponível em: <http://www. scielo.br/pdf/hcsm/v17n4/05.pdf $>$.

Cunha, C. C. Reservas Extrativistas: institucionalização e implementação no Estado brasileiro dos anos 1990. Rio de Janeiro, Tese (Doutorado em Psicossociologia de Comunidades e Ecologia Social) - Universidade Federal do Rio de Janeiro, 2010.

Cunha, M. C. Populações tradicionais e a Convenção da Diversidade Biológica. Estudos Avançados,13(36),147-163, 1999. Disponível em: $<$ http://www.scielo.br/pdf/ea/v13n36/ v13n36a08.pdf>.

Diaz Bordenave, J. E. O que é participação. São Paulo: Brasiliense, 2007. (Coleção Primeiros Passos; 95)

Diegues, A. C. O mito moderno da natureza intocada. São Paulo: Hucitec; NUPAUB- USP, 2001a.

Diegues, A. C. Repensando e recriando as formas de apropriação comum dos espaços e recursos naturais. In: Diegues, A. C.; Castro, A. C. C. (Orgs.). Espaços e recursos naturais de uso comum. São Paulo: NUPAUB-USP, 2001 b. p. 97-124.

Durkheim, É. Da divisão do trabalho social. 2. ed. São Paulo: Martins Fontes, 2004.

Feeny, D.; Berkes, F.; McCay, B. J.; Acheson, J. M. A tragédia dos comuns: vinte e dois anos depois. In: Diegues, A. C.; Castro, A. C. C. (Orgs.). Espaços e recursos naturais de uso comum. São Paulo: NUPAUB-USP, 2001. p. 18-42.

Freire, P. Extensão ou comunicação? Tradução de Rosisca Darcy de Oliveira. Rio de Janeiro: Paz e Terra, 1983.

Goldman, M. Inventando os comuns: teorias e práticas do profissional em bens comuns. In: Diegues, A. C.; Castro, A. C. C. (Orgs.). Espaços e recursos naturais de uso comum. São Paulo: NUPAUB-USP, 2001. p. 43-78.

Greco, P.; Penteado, D.; Salazar, M.; Straatmann, J.; Vasconcelos, V.; Tierno, C.; Neves, L.; Reis, A.; Santos, R. Compartilhando experiências de gestão de Unidades de Conservação: a formação dos conselhos deliberativos das RESEX Riozinho do Anfrísio e Rio Iriri-Terra do Meio,
PA. 2007. Disponível em: <http://www.socioambiental. org/banco_imagens/pdfs/artigo_gestao_UCs_Iriri_Anfrisio2007_final2.pdf>.

Luna, M. B. A. Gestão de espaços de uso comum e manejo participativo: o caso da Reserva Extrativista do Alto Juruá, Acre. Raizes, 23, 52-61, 2004. Disponível em: <http://www. ufcg.edu.br/ raizes/artigos/Artigo_6.pdf>.

Malinowski, B. Argonautas do Pacifico Ocidental. São Paulo: Abril Cultural, 1998 (1922).

Martins, J. B. Observação participante: uma abordagem metodológica para a psicologia escolar. Semina: Ciências Sociais/Humanas, 17(3), 266-273, 1996. Disponível em: $<$ http://www.uel.br/revistas/uel/index.php/seminasoc/article/view/9472/8263>.

Martins, J. S. A reprodução do capital na frente pioneira e o renascimento da escravidão. In: Martins, J. S. Fronteira: a degradação do outro nos confins do humano. São Paulo: Hucitec, 1997. p. 79-112.

Matias-Pereira, J. O processo de ocupação e de desenvolvimento da Amazônia: a implementação de políticas públicas e seus efeitos sobre o meio ambiente. Revista de Informação Legislativa, 34(134), 75-85, 1997. Disponível em: <http:// repositorio.unb.br/bitstream/10482/902/1/ARTIGO_ProcessoOcupacaoAmazonia.pdf $>$.

McGrath, D. Parceiros no crime: o regatão e a resistência cabocla na Amazônia tradicional. Novos Cadernos NAEA, 2(2), 57-72, 1999. Disponível em: <http://www.periodicos. ufpa.br/index.php/ncn/article/view/109/163>.

Medeiros, R.; Young, C. E. F. Contribuição das unidades de conservação brasileiras para a economia nacional: Relatório Final. Brasília: UNEP, 2011.

Milani, C. R. S. Mitos construídos acerca da participação no âmbito da cooperação internacional para o desenvolvimento: um olhar a partir da experiência brasileira recente. In: Carrizo, L.; Gallicchio, E. (Orgs.). Desarrollo Local y Gobernanza: enfoques transdisciplinarios. Montevidéu: CLAEH/UNESCO/CAF, 2006. p. 125-135.

Pimbert, M. P.; Pretty, J. N. Parques, comunidades e profissionais: incluindo "participação" no manejo de áreas protegidas. In: Diegues, A. C. (Org.). Etnoconservação: novos rumos para a proteção da natureza nos trópicos. 2. ed. São Paulo: NUPAUB-USP; Hucitec; Annablume, 2000. p. 183-223. 
Pinton, F.; Aubertin, C. O extrativismo entre conservação e desenvolvimento. In: Castro, E.; Pinton, F. (Orgs.). Faces do trópico úmido: conceitos e novas questões sobre desenvolvimento e meio ambiente. Belém: Cejup: UFPA-NAEA, 1997. p. 263-284.

Porro, N. M. S.; Shiraishi Neto, J.; Veiga, I. Mais uma luta no campo jurídico: pelo conhecimento tradicional no modo de vida das quebradeiras de coco babaçu. São Luís: ASSEMA, COOPAESP, MIQCB, 2012. (Caderno de Estudos de Divulgação).

Porto-Gonçalves, C. W. Amazônia, Amazônias. 2. ed. São Paulo: Contexto, 2005.

Schweickardt, K. Reforma agrária e política ambiental na Amazônia: encontros e desencontros. In: Esterci, N.; Valle, R. S. T. (Orgs.). Reforma agrária e meio ambiente. São Paulo: Instituto Socioambiental, 2003. p. 81-87.

Silva, J. B.; Simonian, L. T. L. População tradicional, reservas extrativistas e racionalidade estatal na Amazônia brasileira. Desenvolvimento e Meio Ambiente, 33, 163-175, 2015. doi: 10.5380/dma.v33i0.36473

Silva, M. R. Estratégias de conservação da floresta amazônica brasileira: importância das unidades de conservação e das florestas privadas na redução do desmatamento. Andalucía - Espanha, Dissertação (Maestría em Conservación y Gestión del Medio Natural) - Universidad Internacional de Andalucía, 2010.
Spínola, J. L.; Cardoso, T. M.; Teixeira, C. Espaços e recursos naturais comuns e o arranjo institucional Reserva Extrativista: uma reflexão sobre benefícios e os desafios do processo de institucionalização. In: Anais do Encontro Nacional da ANPPAS. Florianópolis, 4 de out., 2010.

Vasconcelos, V. O.; Siqueira, C. T. Populações ribeirinhas da Amazônia e preservação da cultura tradicional: dilemas em uma sociedade globalizada, 2008. Disponível em: <http://www.paulofreire.org/pub/FPF2008/TrabalhoValeriaVasconcelos/artigo_Forum_PF_globalizacao.doc $>$.

Vasconcelos, V. O.; Siqueira, C. T.; Santos, R.; Salazar, M.; Straatmann, J.; Neves, L.; Reis, A. R.; Campos, P. C. Educação popular e meio ambiente: diálogos com populações tradicionais amazônicas. Ambiente e Educação, 15(1), 47-66, 2010. Disponível em: <http://www.seer.furg.br/ ambeduc/article/view/879/914>.

Velásquez, C.; Boas, A. V.; Schwartzman, S. Desafio para a gestão ambiental integrada em território de fronteira agrícola no oeste do Pará. Revista de Administração Pública, 40(6), 1061-1075, 2006. Disponível em: <http://www. scielo.br/pdf/rap/v40n6/07.pdf $>$.

Vianna, L. P. De invisíveis a protagonistas: populações tradicionais e unidades de conservação. São Paulo: Annablume; Fapesp, 2008.

Witkoski, A. C. Terras, florestas e águas de trabalho: os camponeses amazônicos e as formas de uso de seus recursos naturais. 2. ed. São Paulo: Annablume, 2010. 